\title{
Genetic variability of brown lacewing, Micromus igorotus Banks (Haemerobidae: Neuroptera) and Dipha aphidivora (Meyrick) (Pyralidae: Lepidoptera) through RAPD markers in sugarcane ecosystem
}

\author{
P.V. MATTI*, C.P. MALLAPUR, K.A. KULKARNI AND D.N. KAMBREKAR \\ Department of Entomology, University of Agricultural Sciences, DHARWAD (KARNATAKA) INDIA
}

\section{ARITCLE INFO \\ Received : 02.08 .2013 \\ Revised : 16.07 .2014 \\ Accepted : 02.08 .2014}

\section{KEY WORDS :}

Genetic similarity, Molecular

chacterization, Micromus igorotus,

Dipha aphidivora, RAPD, PCR
*Corresponding author:

Email:poornimamatti@gmail.com

\begin{abstract}
This study used 10 RAPD markers, to provide insight into the genetic variability through, molecular characterization of brown lacewing and Dipha aphidivora from different geographical locations under laboratory conditions. There existed variation in the DNA profiling among all samples. The dendrogram constructed using symmetric matrix of different samples resulted into two major clusters. The similairity matrix pertaining to different isolates of Micromus igorotus and Dipha aphidivora revealed that the similarity co-efficient ranged from 0.5-0.80 and 0.57-0.80, respectively. The highest genetic similarity index (0.80) of Micromus igorotus was seen between the isolates from Bangalore and Poona followed by 0.6 between the isolates from Bangalore and both Dharwad and Bagalkot. However, the highest genetic similarity index of 0.8 was seen between the isolates Dipha aphidivora from Assam and Poona followed by 0.57 was seen between Bangalore and Dharwad and also from Bangalore and Sameerwadi (Bagalkot).

How to view point the article : Matti, P.V., Mallapur, C.P., Kulkarni, K.A. and Kambrekar, D.N (2014). Genetic variability of brown lacewing, Micromus igorotus Banks (Haemerobidae: Neuroptera) and Dipha aphidivora (Meyrick) (Pyralidae: Lepidoptera) through RAPD markers in sugarcane ecosystem. Internat. J. Plant Protec., 7(2) : 281-286.
\end{abstract}

